\title{
Working
}

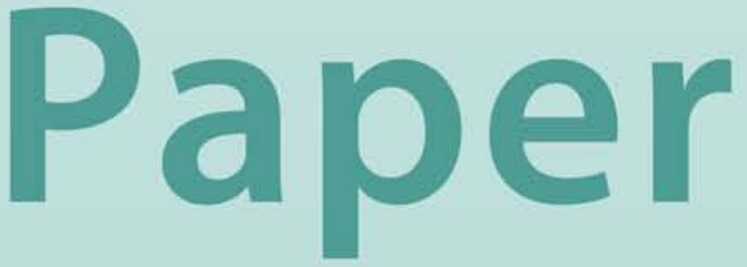




\title{
Altruism and Workers' Remittances: Evidence from Selected Countries in the Middle East and Central Asia
}

\author{
Jacques Bouhga-Hagbe
}




\title{
IMF Working Paper
}

Middle East and Central Asia Department

\section{Altruism and Workers' Remittances: \\ Evidence from Selected Countries in the Middle East and Central Asia}

Prepared by Jacques Bouhga-Hagbe ${ }^{1}$

Authorized for distribution by J. Erik De Vrijer

May 2006

\begin{abstract}

\section{This Working Paper should not be reported as representing the views of the IMF.} The views expressed in this Working Paper are those of the author(s) and do not necessarily represent those of the IMF or IMF policy. Working Papers describe research in progress by the author(s) and are published to elicit comments and to further debate.

Workers' remittances have been playing an increasingly important role in the balance of payments of many countries and can significantly contribute to the strength of their external positions. Assessing the likely stability of remittance flows could be a valuable input to the analysis of their external vulnerabilities. This paper argues that "altruism," as a motive to send money home, would contribute to the stability of these flows. Using a simple framework that relates workers' remittances to agricultural GDP, which is used as an indicator of economic "hardship" in the home country, evidence suggests that altruism could have played an important role in the flow of remittances to Egypt, Jordan, Morocco, Pakistan, and Tunisia in recent years.

JEL Classification Numbers: D10, E20, C12, C22
\end{abstract}

Keywords: Remittances, altruism, co-integration, Egypt, Jordan, Morocco, Pakistan, Tunisia Author(s) E-Mail Address: jbouhgahagbe@imf.org

\footnotetext{
${ }^{1}$ I am grateful to Mohsin S. Khan, J. Erik De Vrijer, and Gene Leon for very helpful comments. All errors and omissions are mine.
} 
Contents

Page

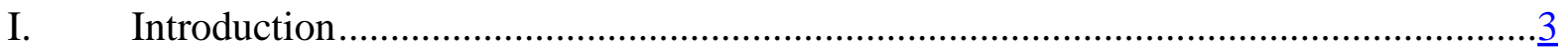

II. Determinants of Workers’ Remittances and Their Implications ...............................

III. Empirical Investigation .................................................................................

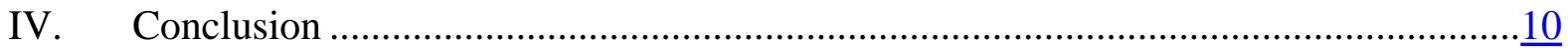

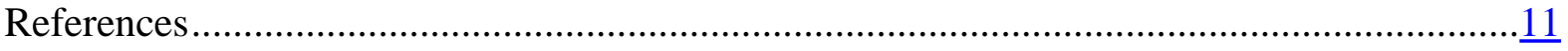

Appendix

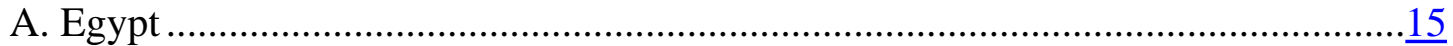

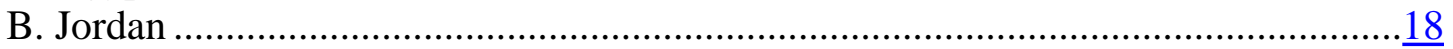

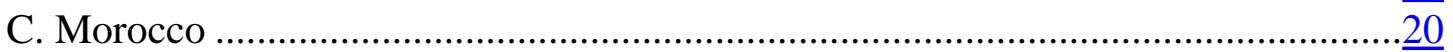

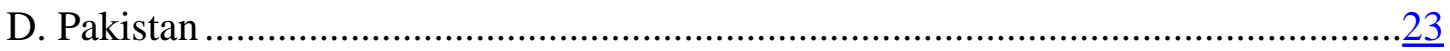

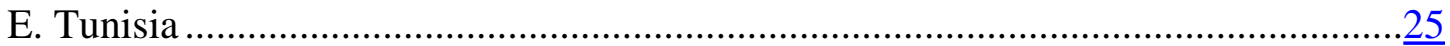

Tables

1. Balance of Payments, 2000-04 Averages .................................................................. 4

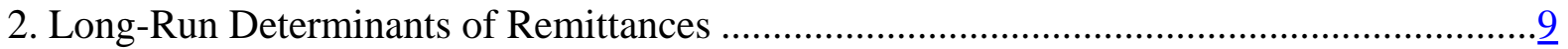

A1. Egypt: Stationarity Test (Elliott-Rothenberg-Stock DF-GLS test)..............................16

A2. Egypt: Cointegration Rank Tests (Trace) .............................................................16

A3. Egypt: Cointegration Rank Tests (Maximum Eigen Value).........................................17

A4. Egypt: Statistical Properties of the Vector Error Correction Model ................................17

A5. Jordan: Stationarity Test (Elliott-Rothenberg-Stock DF-GLS test)..............................18

A6. Jordan: Cointegration Rank Tests (Trace) ................................................................ 19

A7. Jordan: Cointegration Rank Tests (Eigenvalue) .........................................................19

A8. Jordan: Statistical Properties of the Vector Error Correction Model 1/...........................

A9. Morocco: Stationarity Test (Elliott-Rothenberg-Stock DF-GLS test) ............................21

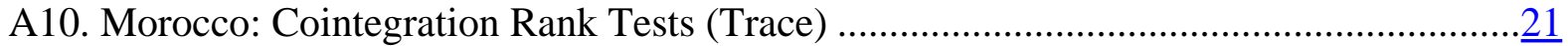

A11. Morocco: Cointegration Rank Tests (Maximum Eigenvalue) ....................................22

A12. Morocco: Statistical Properties of the Vector Error Correction Model ..........................22

A13. Pakistan: Stationarity Test (Elliott-Rothenberg-Stock DF-GLS test) ........................... $\underline{23}$

A14. Pakistan: Cointegration Rank Tests (Trace) ..............................................................24

A15. Pakistan: Cointegration Rank Tests (Maximum Eigenvalue) .......................................24

A16. Pakistan: Statistical Properties of the Vector Error Correction Model..........................25

A17. Tunisia: Stationarity Test (Elliott-Rothenberg-Stock DF-GLS test) ...........................26

A18. Tunisia: Cointegration Rank Tests (Trace) ............................................................

A19. Tunisia: Cointegration Rank Tests (Maximum Eigenvalue) ........................................27

A20. Tunisia: Statistical Properties of the Vector Error Correction Model ............................27 


\section{INTRODUCTION}

People working outside their home country regularly transfer money home. These flows play an increasingly important role in the external positions of the recipient countries. For example, during the period 2000-04, workers' remittances amounted to about 3.5 percent of GDP in Egypt, 20 percent in Jordan, 8 percent in Morocco, 4 percent in Pakistan, and 5 percent in Tunisia. These inflows compare to a trade deficit of about 7.5 percent of GDP in Egypt, 24 percent in Jordan, 10 percent in Morocco, 1.5 percent in Pakistan, and 10 percent in Tunisia (Table 1). Moreover, remittance flows to these countries have been larger than foreign direct investment flows.

In Egypt, the level of remittances is equivalent to more than 15 percent of exports of goods and services. Their contribution to the balance of payments has been close to that of tourism in recent years, and their impact on Egypt's external position has historically been significant.

In Jordan, remittances almost offset the country's trade deficit. They are equivalent to more than 40 percent of exports of goods and services. There is no doubt that these flows greatly contribute to Jordan's external position. In addition, given Jordan's fixed exchange rate regime, remittances affect the growth of monetary aggregates through balance of payment surpluses. Therefore, remittances also matter for the analysis of monetary policy in Jordan.

In Morocco, workers’ remittances represent about 25 percent of exports of goods and services. Their contribution to the balance of payments is equivalent to that of tourism. The impact of workers' remittances on Morocco's external position and the conduct of monetary policy is significant. Remittances almost cover the trade deficit and have contributed to the recent surpluses of the external current account, as well as the overall balance of payments. The balance of payment surpluses have contributed to the liquidity of the banking system and affect the conduct of monetary policy.

In Pakistan, workers' remittances are equivalent to about 22 percent of exports of goods and services. These flows have historically been an important component of Pakistan's balance of payments and have also contributed to the strengthening of the Pakistani rupee. Therefore, remittances play an important role in the country's external position and influence the conduct of monetary and exchange rate policy.

In Tunisia, workers' remittances are equivalent to about 11 percent of exports of goods and services. Their contribution to the balance of payments is just slightly below that of tourism (about 13 percent of exports of goods and services). Even though the relative importance of remittance flows to Tunisia compared to exports of goods and services is smaller than in the other countries we consider in this paper, they certainly contribute to containing vulnerabilities in Tunisia's external position.

In the above countries, the stability of remittance flows is an important policy issue that is relevant for the analysis of their external vulnerabilities. This issue becomes even more important given the fact that all these countries, with the exception of Egypt, are net 
importers of oil, and therefore are likely to experience the negative impact on their external positions of the current high oil prices. Remittances, and tourism for some countries, tend to mitigate the impact of unfavorable shocks on their balance of payments. Remittances also affect the liquidity in their banking systems and, therefore, indirectly influence the conduct of monetary policy. Assessing the stability of such flows could thus also be useful to understanding the challenges these countries face in the conduct of monetary and exchange rate policy.

Table 1. Balance of Payments, 2000-04 Averages

(In percent of GDP)

\begin{tabular}{|c|c|c|c|c|c|}
\hline & Egypt & Jordan & Morocco & Pakistan & Tunisia \\
\hline Current Account Balance & 1.6 & 3.7 & 2.6 & 2.2 & -3.3 \\
\hline Trade Balance & -7.5 & -23.8 & -10.2 & -1.5 & -10.1 \\
\hline Exports of goods & 10.1 & 29.3 & 20.8 & 13.6 & 32.6 \\
\hline Imports of goods & -17.6 & -53.1 & -31.1 & -15.1 & -42.7 \\
\hline Services, net & 4.2 & -1.3 & 5.5 & -1.2 & 6.4 \\
\hline Credit & 12.7 & 18.4 & 12.0 & 2.8 & 13.1 \\
\hline Debit & -8.5 & -19.7 & -6.5 & -4.0 & -6.8 \\
\hline Income, net & 0.2 & 1.6 & -2.0 & -2.9 & -4.6 \\
\hline Current Transfers, net & 4.8 & 27.2 & 9.3 & 7.7 & 5.1 \\
\hline Remittances, credit & 3.5 & 19.9 & 8.2 & 3.6 & 4.8 \\
\hline Capital and Financial Account, net & -2.3 & -5.8 & -2.4 & -2.9 & 3.4 \\
\hline Direct Investment, net & 0.9 & 4.3 & 3.4 & 0.8 & 2.8 \\
\hline Reserve Assets, net & 0.2 & -5.7 & -3.9 & -2.2 & -1.3 \\
\hline Errors and Omissions, net & 0.7 & 2.1 & -0.2 & 0.7 & -0.1 \\
\hline
\end{tabular}

Source: IMF, Balance of Payments and International Investment Position Statistics, and author's calculations

In this paper, we use a simple framework, focusing on "altruism," to assess the stability of remittances to the countries we consider. By "altruism," we mean the willingness of someone, in this case a worker living outside his or her home country, to provide financial assistance to another in a situation of "hardship." We use agricultural GDP as an indicator of "hardship" to analyze the role of altruistic motives as determinants of these flows. We argue below why agricultural GDP could be a useful indicator of economic "hardship." A trend variable is used to capture the effects of other potential motives to remit. Including a trend as we do in the framework has implications that we later discuss. Using cointegration techniques, we find evidence suggesting that altruism could be playing an important role in workers' decision to send money to Egypt, Jordan, Morocco, Pakistan, and Tunisia. For all these countries, the coefficient on the variable "agricultural GDP" in the equation determining the level of remittances turns out to be significant and negative. These findings suggest that in the long run, when agricultural GDP in these countries falls, workers' remittances tend to increase. Since we argue that agricultural GDP can be seen as a good indicator of "hardship" in the above-mentioned countries, we interpret this finding as 
evidence of altruism in workers' decisions to send money home. We then conclude that because of the "solidarity" motives that partly drive remittances to the countries we study, a sudden drop or reversal of these flows is unlikely in a foreseeable future, as those who receive this assistance are likely to continue to depend on them for a while.

The literature on remittances can be divided in two segments, one focusing on the causes and uses of remittances and the other on the macroeconomic impact of remittances. ${ }^{2}$ The first segment emphasizes the role of altruism and family ties as a motivation for remittances. ${ }^{3}$ However, some other theories have focused on the idea that there can be self-interested reasons for remitting as well, which nevertheless center on the family. ${ }^{4}$ Chami and Fisher (1996) argue that these arrangements may not be as self-interested as they may appear and show that altruism can lead to risk-sharing arrangements that are self-enforcing. Other studies have examined the possibility of having portfolio investment motives behind remittances. ${ }^{5}$ Regarding the macroeconomic impact of remittances in the recipient countries, the literature tends to emphasize that remittances increase family consumption and are not invested in productive assets, with the possible exception of real estate. ${ }^{6}$

This paper can be seen as part of the literature on workers' motives to remit. It adds to the investigation of the causes of remittances discussed above. However, a distinguishing feature is that we apply a relatively simple framework to selected countries, which we study individually. By doing this, we avoid the potential problems that can arise when pieces of information about individual countries are pooled together to analyze phenomena whose main characteristics could be country-specific. ${ }^{7}$ Another distinguishing feature of this analysis is that cointegration techniques help us avoid any data transformation, such as for example differencing, which could lead to a loss of information. The estimation is based on

\footnotetext{
2 See for example Taylor (1999) and Elbadawi and Rocha (1992), Russell (1986), and more recently, Chami, Fullenkamp, and Jahjah (2005) for a review of the literature on remittances.

3 See for example Johnson and Whitelaw (1974), and Lucas and Stark (1988).

${ }^{4}$ Lucas and Stark (1985) find evidence for self-interested behavior in Botswana and suggest that one reason for remitting could be that migrants may have investments that need attention while they are away. See also Stark (1991), Agarwal and Horowitz (2002), Gubert (2002), Abel and Kotlikoff (1988), Altonji, Hayashi, and Kotlikoff (1992), Townsend (1994), Poirine (1997), and Ilahi and Jafarey (1999), among others.

${ }^{5}$ See for example Straubhar (1986), Wahba (1991), and, more recently, Gordon and Gupta (2004).

6 See Oberai and Singh (1980), Durand and others (1996), Gilani (1981), Glytsos (1993), Alderman (1996), Adams (1991, 1998), Brown (1997), Sofranko and Idris (1999), Lopez and Seligson (1991), Taylor (1992), Stahl and Habib (1989), Nishat and Bilgrami (1991), Glytsos (1993), Adelman and Taylor (1990), Durand, Parrado, and Massey (1996), Kozel and Alderman (1990), Itzigsohn (1995), Amjad (1986), Ahmed (1986), and Chami, Fullenkamp, and Jahjah (2005).

${ }^{7}$ Bouhga-Hagbe (2004) does a similar exercise for Morocco.
} 
(the logarithm of) the original variables, thus leading directly to the estimation of the longrun relation among the variables. Endogeneity problems will not be a concern because the technique allows for endogenous regressors.

The paper is organized as follows. In Section II, we discuss the potential motives to remit and argue how each could contribute or not to the stability of remittance flows. Section III is devoted to the empirical investigation of the relation between remittances and their potential determinants in the countries we consider. We then present our concluding remarks, including the implications of our findings as well as the limitations of the framework we use.

\section{DETERMINANTS OF WORKERS’ REMITTANCES AND THEIR IMPLICATIONS}

As reflected in the extensive literature we briefly mentioned above, many factors are significant in workers' decisions to remit. The importance of each of these factors in each country can shed light on the stability of remittance flows, which are usually an important component of a country's balance of payments.

Altruism or solidarity motives can a priori be expected to be an important factor in workers' decision to remit as many workers partly send money home to support their families. If such a motive is important in workers' decisions to remit, one would expect remittance flows to remain stable in developing countries, as it is likely that in such countries many of the families receiving assistance from abroad will continue to depend on such flows in the foreseeable future. However, the stability of such motives should also be seen in the context of changes in migration patterns. For instance, the migration of family members may reduce the scope for "altruistic" motives. Nonetheless, in many developing countries, this effect would be counterbalanced by new waves of emigrants who are attracted by jobs in industrialized countries. Moreover, "altruism” as a motive to remit may in fact partly reflect self-interested reasons for transfers for those who want their residential investments to be looked after when they are away. Therefore, "altruistic" flows could be thought of as being fairly stable.

“Attachment to homeland" can also be an important motive in someone's decision to send money home. Workers can send money home because they want to build "something in their homeland.” In many cases, workers remit partly to buy real estate or to create a small business. One can expect such motives to remain stable and therefore, to contribute to the stability of remittances in the long run. However, improved settlement opportunities for workers in their countries of residence may in theory reduce their attachment to their homeland. Nonetheless, these improvements in settlement opportunities could be expected to occur at a slow pace, therefore having only a limited offsetting impact on workers' attachments to their home countries.

Remittances can also reflect workers' desires to diversify their portfolios. The presence of such portfolio diversification motives would imply that remittances could be sensitive to their rate of return. In this case, they could be volatile just as any other capital flow. 
The exchange rate can also influence the level of remittances. The overall effect of exchange rate movements is not always clear a priori because it is the sum of two opposite effects. If goods in the home country become less expensive with the depreciation of the currency, one does not need to transfer as much money as before to buy a given amount of goods. On the other hand, a depreciation of the home country's exchange rate can also make its citizens living abroad "wealthier," as it increases their purchasing power in the home country. Therefore, this "wealth effect" could give them incentives to transfer more money in order to buy even more goods in the home country, including residential real estate, which are now less expensive. Even if the actual effect of exchange rate movements were known, interpreting their long-term impact on the stability of remittances would be difficult. ${ }^{8}$

Finally, other factors such as national policies toward workers living abroad could be an important qualitative determinant of transfers in general. For example, in Morocco, there is a ministry in charge of Moroccans living abroad, which, among other things, helps streamline the administrative procedures related to their transactions with the home country. Such aspects of a country's policy, if important in workers' decisions to remit, would contribute to the stability of remittance flows.

\section{EMPIRICAL INVESTIGATION}

In this analysis, we focus exclusively on altruism as a motive to remit. Other potential motives to remit, with the exception of the exchange rate, are captured in a linear trend variable. Although intuitively appealing, one could note that this could be a strong assumption for some countries if other motives to send money home cannot easily be captured in a linear trend. ${ }^{9}$ The size of the sample, the availability of the data on other potential motives to send money home, our focus on altruism, and our desire to keep the econometric framework simple have also influenced our decision. We decided to keep the exchange rate in the regression equation for at least two reasons. First, many countries tend to manage their exchange rates even when it is flexible. Therefore, a trend may not

\footnotetext{
${ }^{8}$ For example, even if a devaluation or a depreciation of a currency can temporarily attract flows from workers who are willing to buy goods in their home country because they have become less expensive, this factor can in theory also undermine their confidence in the economy if it is a consequence of some weaknesses in the economy.

${ }^{9}$ Bouhga-Hagbe (2004) presents a similar analysis for Morocco that explicitly includes the other potential motives to remit that we have discussed. The assumption we make is not necessarily unrealistic because other motives to remit mainly include workers' willingness to share additional revenues with their families and a willingness to "build something" in the homeland. Wages, GDP in workers' countries of residence, and nonagricultural GDP in the home country, particularly construction GDP can be used to capture such motives. Portfolio diversification motives may not be captured with a trend because they may depend on financial indicators such as interest rates differentials that may not be trend stationary. However, these motives to remit are likely to play a limited role in remittance flows to the countries we consider. Bouhga-Hagbe (2004) finds that they do not play any significant role in the case of Morocco. In general, the empirical investigations of remittances we mention above suggest that demographic and income variables tend to be significant, while financial variables' significance varies depending on the sample and specification.
} 
accurately capture the information contained in exchange rate movements. Second, the exchange rate also captures differences in units of account, in addition to being a potential motive to remit. Keeping this variable in the regression equation allows us to control for changes in the level of remittances that come merely from changes in relative units of account. Therefore, we estimate the following long-run relation

$$
\text { Remittances }=\alpha \text { Agricultural GDP }+\beta \text { Exchange rate }+\gamma \text { Trend }+\varepsilon
$$

where agricultural real GDP is used as a proxy for "hardship" in the countries we analyze. A fall in real agricultural GDP is interpreted as an increase in "hardship." One could note that when agricultural GDP falls, food prices could in theory increase. Therefore, the impact on farmers' revenues is unclear and would depend on the elasticity of agricultural output to food prices. However, one could also note that even when farmers' revenues are roughly unchanged, their purchasing power is likely to decrease with the hike in prices in the economy. ${ }^{10}$ Therefore a decline in real agricultural GDP is likely to make farmers worse off. ${ }^{11}$

In equation ( 1 ), the variable "Remittances" is the logarithm of the yearly dollar value of the flow of remittances received by a country. "Agricultural GDP” is the logarithm of its real agricultural GDP in local currency. ${ }^{12,13}$ "Exchange rate" is the logarithm of its exchange rate (US dollar per national currency). The variable "Trend" is a linear trend. " $\varepsilon$ " is an error term that is assumed to be stationary. Evidence of altruism can be captured by a negative long-run correlation between the variables "Remittances" and "Agricultural GDP" $(\alpha<0)$.

Using cointegration techniques, we estimate the long-run relation between remittances and some of their potential determinants for Egypt, Jordan, Morocco, Pakistan, and Tunisia, as we describe in equation ( 1 ). The results are presented in Table 2 . The details of the

\footnotetext{
${ }^{10}$ Countries tend to import more food products when their agricultural campaign is bad. This contributes to limiting the increase in food prices. In addition, it also contributes to lowering both farmers' revenues and the general price level in the economy.

${ }^{11}$ Another argument supporting this view is that if a relatively low agricultural output were to make farmers better off, farmers would tend to keep their supply of food at relatively low levels, even when the agricultural campaign is good.

${ }^{12}$ Nominal agricultural GDP is not appealing to us because it depends on food prices which are affected not only by the quality of a country's agricultural campaign, but also by governments' foreign trade policies. A government that lowers tariffs on agricultural products will contribute to lowering food prices in its economy. For a given real agricultural GDP, nominal agricultural GDP would fall. However, it is not clear whether farmers will be worse off because if their output is relatively high, they could still have a relatively high level of revenues and enjoy a higher purchasing power because of a fall in domestic prices. Therefore, changes in nominal agricultural GDP may not reflect changes in the level of "hardship" and could merely reflect changes in countries' foreign trade policies.

${ }^{13}$ For Tunisia, we use remittances in local currency. More details are provided in the appendix.
} 
econometric technique for each of the countries are presented in the appendix. The statistical properties of the model used do not suggest any problem.

Table 2. Long-Run Determinants of Remittances

\begin{tabular}{|c|c|c|c|c|c|c|c|}
\hline \multirow{2}{*}{$\begin{array}{l}\text { Dependent variable } \\
\text { Remittances }\end{array}$} & \multicolumn{2}{|c|}{ Egypt } & \multicolumn{2}{|c|}{ Jordan } & \multirow[t]{2}{*}{ Morocco } & \multirow[t]{2}{*}{ Pakistan } & \multirow[t]{2}{*}{ Tunisia } \\
\hline & & & & & & & \\
\hline Agricultural GDP & $\begin{array}{r}-9.59 \\
{[-3.91]}\end{array}$ & $\begin{array}{r}-12.28 \\
{[-3.27]}\end{array}$ & $\begin{array}{r}-0.32 \\
{[-1.61]}\end{array}$ & $\begin{array}{r}-0.78 \\
{[-2.55]}\end{array}$ & $\begin{array}{r}-1.37 \\
{[-3.26]}\end{array}$ & $\begin{array}{r}-13.59 \\
{[-6.38]}\end{array}$ & $\begin{array}{r}-2.53 \\
{[-3.82]}\end{array}$ \\
\hline Exchange rate & $\begin{array}{r}0.158 \\
{[2.48]}\end{array}$ & & $\begin{array}{r}0.93 \\
{[1.82]}\end{array}$ & & $\begin{array}{r}-1.23 \\
{[-3.81]}\end{array}$ & $\begin{array}{r}1.35 \\
{[1.78]}\end{array}$ & \\
\hline Trend & $\begin{array}{r}0.30 \\
{[3.92]}\end{array}$ & $\begin{array}{r}0.36 \\
{[3.45]}\end{array}$ & $\begin{array}{r}0.06 \\
{[2.63]}\end{array}$ & $\begin{array}{r}0.026 \\
{[1.26]}\end{array}$ & $\begin{array}{r}0.02 \\
{[1.64]}\end{array}$ & $\begin{array}{r}0.63 \\
{[6.08]}\end{array}$ & $\begin{array}{r}0.18 \\
{[7.87]}\end{array}$ \\
\hline
\end{tabular}

Source: Author's estimates

$1 / \mathrm{t}$-statistics are in brackets.

The data are taken from the World Development Indicators database and cover the period 1977-2002 for Egypt, 1975-2002 for Jordan and Morocco, and 1976-2002 for Pakistan and Tunisia.

All regression equations include an unreported constant.

The estimate of the coefficient $\alpha$ on "Agricultural GDP" in Table 2 is negative for all five countries we study. Exclusion tests suggest that the variable "Agricultural GDP" significantly enters the long-run relation for each of the countries (see Table A4 for Egypt, Table A8 for Jordan, Table A12 for Morocco, Table A16 for Pakistan, and Table A20 for Tunisia). These results suggest that the statistical model we present in equation ( 1 ) could explain the evolution of remittances in the long-run in these five countries and that the variable "Agricultural GDP" significantly enters the long-run relation with the sign expected. ${ }^{14}$ As argued above, these findings support the view that altruism played an important role in workers' decision to send money to Egypt, Jordan, Morocco, Pakistan, and Tunisia during this period.

\footnotetext{
${ }^{14}$ As far as the magnitude of the coefficient $\alpha$ on "Agricultural GDP" is concerned, one could note that in Table 2, it is much higher for Egypt and Pakistan than for the other three countries. These magnitudes are only marginally affected when alternative lag specifications are considered in the model. This could suggest that the long-run level of remittances in Egypt and Pakistan may also be affected by other variables that are not well captured either by the lag values of the variables we consider or by a linear trend. The instability of this parameter in the models we present for Egypt and Jordan could be due to the small size of our sample. As far as the coefficient on the variable "Exchange rate" is concerned, its sign and magnitude are more difficult to interpret, as we argue above.
} 


\section{Conclusion}

Our purpose in this paper was to look for potential evidence of altruistic motives behind workers' decisions to remit to selected countries in the Middle East and Central Asia. Evidence of such motives could shed light on the stability of remittance flows to these countries, which tend to be a sizable component of the balance of payments. Using a relatively simple framework, empirical evidence suggests that in the long-run, remittances tend to be negatively correlated with agricultural GDP, which we use as an indicator of "hardship.” This finding supports the view that "altruism" could be playing an important role in workers' decisions to remit to the countries analyzed. It also implies that a sudden drop or reversal of remittance flows to the countries we consider is unlikely in a foreseeable future, as many of those who are receiving this assistance will likely continue to depend on it in the coming years. Therefore, remittances are likely to continue to be an important element mitigating the external vulnerabilities of the countries considered.

In this analysis, we mainly focus on finding evidence of altruism as a motive for workers' decision to remit. Therefore, we use a framework that is as simple as possible and easily applicable to countries with relatively few observation points. Our simple framework has some limitations. First, we use a linear trend to capture the effects of other motives to remit besides altruism. These motives could have been introduced explicitly as in Bouhga-Hagbe (2004) for Morocco. Second, we could not clearly quantify the relative importance of altruistic motives compared to other motives. The fact that the trend, which captures other potential motives to remit was significant in our estimates suggests that other motives to remit could also be important. This is left for further research. 


\section{REFERENCES}

Abel, A., and L. Kotlikoff, 1988, "Does the Consumption of Different Age Groups Move Together? A New Nonparametric Test of Intergenerational Altruism,” NBER Working Paper No. 2490 (Cambridge, Massachusetts: National Bureau of Economic Research).

Adams, R.H.Jr., 1991, “The Economic Uses and Impact of International Remittances in Rural Egypt,” Economic Development and Cultural Change, Vol. 39, pp. 695-722.

— 1998, "Remittances, Investment, and Rural Asset Accumulation in Pakistan,” Economic Development and Cultural Change, Vol. 47, pp. 155-73.

Adelman I., and J.E. Taylor, 1990, "Is Structural Adjustment with a Human Face Possible? The Case of Mexico,” Journal of Development Studies, Vol. 26, pp. 387-407.

Agarwal, R., and A.W. Horowitz, 2002, “Are International Remittances Altruism or Insurance? Evidence from Guyana Using Multiple-Migrant Households,” World Development, Vol. 30, pp. 2033-44.

Ahmed, M.A., 1986, “Comments on Impact of Workers’ Remittances from the Middle East on Pakistan’s Economy: Some Selected Issues,” Pakistan Development Review, Vol. 25, pp. 783-85.

Alderman, H., 1996, “Saving and Economic Shocks in Rural Pakistan,” Journal of Development Economics, Vol. 51, pp. 343-65.

Altonji, J., F. Hayashi, and L. Kotlikoff, 1992, "Is the Extended Family Altruistically Linked? Direct Tests Using Micro Data,” American Economic Review, Vol. 82, pp. 1177-98.

Amjad, R., 1986, “Impact of Workers’ Remittances from the Middle East on Pakistan’s Economy: Some Selected Issues,” Pakistan Development Review, Vol. 25, pp. 757-82.

Banerjee, A., Hendry, D.F. and Smith, G.W., 1986, "Exploring Equilibrium Relationships in Economics through Static Models: Some Monte Carlo Evidence,” Oxford Bulletin of Economics and Statistics, Vol. 48, pp. 253-77.

Bouhga-Hagbe, Jacques, 2004, “A Theory of Workers’ Remittances with an Application to Morocco,” IMF Working Paper 04/194 (Washington: International Monetary Fund).

Brown, R.P.C., 1997, “Estimating Remittance Functions for Pacific Island Migrants,” World Development, Vol. 25, pp. 613-26. 
Chami, Ralph, Connel Fullenkamp, and Samir Jahjah, 2005, “Are Immigrant Remittance Flows a Source of Capital for Development?” IMF Staff Papers, Vol. 52, No. 1, pp. 55-81.

Chami, Ralph, and Jeffrey H. Fisher, 1996, “Altruism, Matching, and Nonmarket Insurance,” Economic Inquiry, Vol. 34, pp. 630-47.

Dickey, D.A., and R.J. Rossana, 1994, “Cointegrated Time Series: A Guide Estimation and Hypothesis Testing,” Oxford Bulletin of Economics and Statistics, Vol. 56, pp. 32553.

Durand, J., E.A. Parrado, and D.S. Massey, 1996, “Migradollars and Development: A Reconsideration of the Mexican Case,” International Migration Review, Vol. 30, pp. 423-44.

Durand, J., W. Kandel, E.A. Parrado, and D.S. Massey, 1996, “International Migration and Development in Mexican Communities,” Demography, Vol. 33, pp. 249-64.

Elbadawi, Ibrahim A., and Robert de Rezende Rocha, 1992, "Determinants of Expatriate Workers’ Remittances in North Africa and Europe,” World Bank Policy Research Working Paper 1038 (Washington: World Bank).

Elliott, G, T.J. Rothenberg, and J.H. Stock, 1996, "Efficient Tests for an Autoregressive Unit Root,” Econometrica Vol. 64, No. 4 pp. 813-36.

Engle, R.F., and C.W.J. Granger, 1987, “Co-Integration and Error Correction Representation, Estimation, and Testing,” Econometrica, Vol. 55, No. 2 (March), pp. 251-76.

Glytsos, N.P., 1993, “Measuring the Income Effects of Migrant Remittances: A Methodological Approach Applied to Greece,” Economic Development and Cultural Change, Vol. 42, pp. 131-68.

Gordon, J., and P. Gupta, 2004, “Nonresident Deposits in India: In Search of Return?” IMF Working Paper 04/48 (Washington: International Monetary Fund).

Granger C.W.J., and P. Newbold, 1974, “Spurious Regressions in Econometrics,” Journal of Econometrics, Vol. 2, pp. 111-20.

Gubert, Flore, 2002, "Do Migrants Insure Those Who Stay Behind? Evidence from the Kayes Area (Western Mali),” Oxford Development Studies, Vol. 30, pp. 267-87.

Hendry D.F, and G.E. Mizon, 1993, “Evaluating Econometric Models by Encompassing the VAR,” in Models, Methods, and Applications of Econometrics: Essays in Honor of A.R. Bergstrom, ed. by P.C.B. Phillips (Oxford: Blackwell Publishing). 
Ilahi, N., and S. Jafarey, 1999, "Guest Worker Migration, Remittances, and the Extended Family: Evidence from Pakistan,” Journal of Development Economics, Vol. 58, pp. 485-512.

Itzigsohn, J., 1995, “Migrant Remittances, Labor Markets, and Household Strategies: A Comparative Analysis of Low-Income Household Strategies in the Caribbean Basin," Social Forces, Vol. 74, pp. 633-55.

Johansen, S., 1991, "Estimation and Hypothesis Testing of Cointegration Vectors in Gaussian Vector Autoregressive Models,” Econometrica, Vol. 59, No. 6, (November), pp. 1551-80.

Johansen, S., and K. Juselius, 1992, “Testing Structural Hypothesis in Multivariate Cointegration Analysis of the PPP and the UIP for the UK,” Journal of Econometrics, Vol. 53, pp. 211-44.

— 1994, "Identification of the Long-Run and the Short-Run Structure: An Application to the IS/LM Model,” Journal of Econometrics, Vol. 63. pp. 7-36.

Johnson, G.E., and W.E. Whitelaw, 1974, "Urban-Rural Income Transfers in Kenya: An Estimated-Remittances Function,” Economic Development and Cultural Change, Vol. 22, pp. 473-79.

Kozel, V., and H. Alderman, 1990, "Factors Determining Work Participation and Labour Supply Decisions in Pakistan’s Urban Areas,” Pakistan Development Review, Vol. 29, pp. 1-18.

Kremers, J.J.M., N.R. Ericsson, and J.J. Dolado, 1992, “The Power of Integration Tests,” Oxford Bulletin of Economics and Statistics, Vol. 54, pp. 325-48

Lopez, J.R., and M.A. Seligson, 1991, "Small Business Development in El Salvador: The Impact of Remittances,” in Migration, Remittances and Small Business Development: Mexico and Caribbean Basin Countries, ed. by Sergio Diaz-Briquets and Sidney Weintraub, Series on Development and International Migration in Mexico, Central America, and the Caribbean Basin, Vol. 4 (Boulder, Colorado: Westview Press).

Lucas, Robert E.B., and Oded Stark, 1985, "Motivations to Remit: Evidence from Botswana,” Journal of Political Economy, Vol. 93, pp. 901-18.

— 1988, “Migration, Remittances and the Family,” Economic Development and Cultural Change, Vol. 36, pp. 465-81.

Mackinnon, J.G, 1996, “Numerical Distribution Functions for Unit Root and Cointegration Tests," Journal of Applied Econometrics Vol. 11, No. 6, pp. 601-18. 
Nishat, M., and N. Bilgrami, 1991, “The Impact of Workers’ Remittances on Pakistan Economy,” Pakistan Economic and Social Review, Vol. 29, pp. 21-41.

Oberai, A.S., and H.K.M. Singh, 1980, "Migration, Remittances and Rural Development: Findings of a Case Study in the Indian Punjab,” International Labour Review, Vol. 119, pp. 229-41.

Phillips, P.C.B., 1986, “Understanding Spurious Regressions in Econometrics,” Journal of Econometrics, Vol. 33, pp. 311-40.

Poirine, Bernard, 1997, “A Theory of Remittances as an Implicit Family Loan Arrangement,” Word Development, Vol. 25, pp. 589-611.

Russell, S. Stanton, 1986, "Remittances from International Migration: A Review in Perspective,” World Development, Vol. 14, pp. 677-96.

Sofranko, A.J., and K. Idris, 1999, "Use of Overseas Migrants’ Remittances to the Extended Family for Business Investment: A Research Note,” Rural Sociology, Vol. 64, pp. 464-81.

Stahl, C.W., and A. Habib, 1989, “The Impact of Overseas Workers’ Remittances on Indigenous Industries: Evidence from Bangladesh,” The Developing Economies, Vol. 27, pp. 269-85.

Stark, Oded, 1991, “Migration in LDCs: Risk, Remittances, and the Family,” Finance and Development, December, pp. 39-41.

Straubhar, T., 1986, “The Determinants of Workers’ Remittances: The Case of Turkey,” Weltwirtschaftliches Archiv, Vol. 122, pp. 728-40.

Taylor, J.E., 1992, "Remittances and Inequality Reconsidered: Direct, Indirect, and Intertemporal Effects,” World Bank Staff Working Paper 481 (Washington: World Bank).

— 1999, "The New Economics of Labor Migration and the Role of Remittances in the Migration Process,” International Migration, Vol. 37, pp. 63-88.

Townsend, R.M., 1994, “Risk and Insurance in Village India,” Econometrica, Vol. 62, pp. 539-91.

Wahba, S., 1991, “What Determines Workers’ Remittances?” Finance and Development, December, pp. 41-44.

Yule, G.U., 1926, “Why Do We Sometimes Get Nonsense Correlations between Time Series? A Study in Sampling and the Nature of Time Series," Journal of the Royal Statistical Society, Vol. 89, pp. 1-64. 


\begin{abstract}
APPENDIX
Details on the econometric technique we used are presented below for each of the countries we study.
\end{abstract}

\title{
A. Egypt
}

We started the econometric analysis of remittances to Egypt by first testing the order of integration of the variables used (Table A1). ${ }^{15}$ All the variables are integrated of order one. After a series of tests, a first Vector Error Correction Model (VECM) that was estimated used four lags. The Johansen (1991) tests suggested the existence of a long-run relation as presented in equation ( 1 ). The estimated long-run relation is presented in Table 2 . However, exclusion tests on the coefficient $\beta$ on the exchange rate suggested that the exchange rate may not significantly enter this long-run relation $(\chi 2(1)=2.22$, (prob=0.14)). As a consequence, we estimated a second VECM without the exchange rate. After a series of tests, only one lag was included in the VECM. The Johansen Trace tests suggested the existence of a long-run relation at 10 percent level of significance (Table A2), and the Johansen eigenvalue tests suggested the existence of a long-run relation at 5 percent level of significance (Table A3). The estimated cointegration relation from this second VECM is also presented in Table 2. The statistical properties of the VECM without the exchange rate ( $\beta=0$, in equation ( 1$)$ ) are described in Table A4. The multivariate Lagrange Multiplier (LM) statistics show that the residuals are not autocorrelated. The multivariate Jarque-Bera (JB) test does not reject the hypothesis of normality of residuals. Exclusion tests suggest that all variables included in the cointegration relation are significant at 5 percent level of significance. Therefore, the model presented in equation ( 1 ) could explain the flow of remittances to Egypt.

\footnotetext{
${ }^{15}$ The data are taken from the World Development Indicators database and cover the period 1977-2002.
} 
Table A1. Egypt: Stationarity Test (Elliott-Rothenberg-Stock DF-GLS test) 1/

\begin{tabular}{|c|c|c|c|c|c|c|c|c|}
\hline Variables & $\begin{array}{l}\text { Included in } \\
\text { regression }\end{array}$ & Lag 2 & $2 /$ & Test statistic & $\begin{array}{c}1 \text { percent critical } \\
\text { value } 3 /\end{array}$ & $\begin{array}{c}5 \text { percent critical } \\
\text { value } 3 /\end{array}$ & $\begin{array}{c}10 \text { percent } \\
\text { critical value } 3 /\end{array}$ & Conclusion \\
\hline \multicolumn{9}{|l|}{ In levels } \\
\hline Remittances & constant & & 0 & -1.97 & -2.66 & -1.96 & -1.61 & Unit root \\
\hline Agricultural GDP & constant & & 3 & 1.42 & -2.67 & -1.96 & -1.61 & Unit root \\
\hline exchange rate & constant & & 2 & 0.10 & -2.67 & -1.96 & -1.61 & Unit root \\
\hline \multicolumn{9}{|l|}{ In first difference } \\
\hline $\mathrm{D}$ (Remittances) & constant, trend & & 0 & -4.82 & -3.77 & -3.19 & -2.89 & Stationary \\
\hline D(Agricultural GDP ) & constant, trend & & 0 & -3.94 & -3.77 & -3.19 & -2.89 & Stationary \\
\hline D(exchange rate) & constant & & 1 & -3.49 & -2.67 & -1.96 & -1.61 & Stationary \\
\hline
\end{tabular}

Source: Author's estimates

1/ The test used is the one proposed by Elliott, Rothenberg, and Stock (1996). The null hypothesis is that the variable has a unit root.

2/ The number of lags is selected using the Akaike information criterion. The maximum number of lags used is 5,

except in the model of D(Agricultural GDP) with a constant and a trend, where the maximum number of lags is 10.

3/ For the regression equations, the critical values are from MacKinnon (1996).

Table A2. Egypt: Cointegration Rank Tests (Trace)

\begin{tabular}{crrrr}
$\begin{array}{c}\text { Hypothesized } \\
\begin{array}{c}\text { No. of Cointegration } \\
\text { Equations }\end{array}\end{array}$ & Eigenvalue & Trace & 0.05 & \\
& & Statistic & Critical Value & Prob. \\
\hline None & 0.57 & 24.24 & 25.87 & 0.079 \\
At most 1 & 0.15 & 3.86 & 12.52 & 0.76 \\
& & & & \\
\hline
\end{tabular}

Source: Author's estimates 
Table A3. Egypt: Cointegration Rank Tests (Maximum Eigenvalue)

\begin{tabular}{crrrr}
\hline $\begin{array}{c}\text { Hypothesized } \\
\text { No. of Cointegration } \\
\text { Equations }\end{array}$ & Eigenvalue & Statistic & Critical Value & Prob. \\
& & & & \\
& 0.57 & 20.39 & 19.39 & 0.036 \\
None & 0.15 & 3.86 & 12.52 & 0.76 \\
At most 1 & & & & \\
\hline
\end{tabular}

Source: Author's estimates

Table A4. Egypt: Statistical Properties of the Vector Error Correction Model 1/

\begin{tabular}{|c|c|c|c|c|c|c|}
\hline \multicolumn{7}{|c|}{ Multivariate tests } \\
\hline & 1 & 2 & 3 & 4 & 5 & 6 \\
\hline LM test & $\begin{array}{r}6.03 \\
{[0.20]}\end{array}$ & $\begin{array}{r}4.88 \\
{[0.30]}\end{array}$ & $\begin{array}{r}1.98 \\
{[0.74]}\end{array}$ & $\begin{array}{r}3.14 \\
{[0.53]}\end{array}$ & $\begin{array}{r}2.45 \\
{[0.65]}\end{array}$ & $\begin{array}{r}6.28 \\
{[0.18]}\end{array}$ \\
\hline Normality JB & & & $\begin{array}{c}4.93 \\
{[0.29]}\end{array}$ & & & \\
\hline Skewness & & & $\begin{array}{c}4.41 \\
{[0.11]}\end{array}$ & & & \\
\hline Excess kurtosis & & & $\begin{array}{c}0.51 \\
{[0.77]}\end{array}$ & & & \\
\hline
\end{tabular}

\begin{tabular}{lrr}
\hline \multicolumn{3}{c}{ Univariate tests } \\
\hline & Remittances & $\begin{array}{c}\text { Agricultural } \\
\text { GDP }\end{array}$ \\
\hline Weak exogeneity & 5.86 & 5.87 \\
& {$[0.02]$} & {$[0.02]$} \\
Exclusion test & 16.46 & 7.79 \\
& {$[0.00]$} & {$[0.00]$} \\
Normality JB & 2.60 & 2.32 \\
& {$[0.27]$} & {$[0.31]$} \\
\hline
\end{tabular}

Source: Author's estimates

1/ Numbers in brackets are p-values 


\section{B. Jordan}

We again started the econometric analysis of remittances to Jordan by first testing the order of integration of the variables used (Table A5). ${ }^{16}$ All the variables are integrated of order one. After a series of tests, the VECM we first estimated included four lags. The Johansen tests suggested the existence of a long-run relation as presented in equation ( 1 ). The estimated long-run relation is presented in Table 2 . However, exclusion tests on the coefficient $\beta$ on the exchange rate indicated that the exchange rate may not significantly enter this long-run relation $\left(\chi^{2}(1)=1.53\right.$, (prob=0.21)). We then estimated another VECM without the exchange rate. After a series of tests, four lag were included in this VECM. Both the Johansen and Trace tests suggested the existence of a long-run relation at 5 percent level of significance (Tables A6 and A7). The estimated cointegration relation of this second VECM is also presented in Table 2. The statistical properties of the VECM without the exchange rate ( $\beta=0$, in equation ( 1 )) are described in Table A8. The multivariate LM statistics show that the residuals are not autocorrelated. The multivariate JB test does not reject the hypothesis of normality of residuals. Exclusion tests suggest that all variables included in the cointegration relation are significant at 1 percent level of significance. Therefore, the model presented in equation ( 1 ) could explain the flow of remittances to Jordan.

Table A5. Jordan: Stationarity Test (Elliott-Rothenberg-Stock DF-GLS test) 1/

\begin{tabular}{|c|c|c|c|c|c|c|c|c|}
\hline Variables & $\begin{array}{l}\text { Included in } \\
\text { regression }\end{array}$ & Lag 2 & & Test statistic & $\begin{array}{c}1 \text { percent critical } \\
\text { value } 3 /\end{array}$ & $\begin{array}{c}5 \text { percent critical } \\
\text { value } 3 /\end{array}$ & $\begin{array}{c}10 \text { percent } \\
\text { critical value } 3 /\end{array}$ & Conclusion \\
\hline \multicolumn{9}{|l|}{ In levels } \\
\hline Remittances & constant & & 0 & -1.18 & -2.65 & -1.95 & -1.61 & Unit root \\
\hline Agricultural GDP & constant & & 0 & -1.30 & -2.65 & -1.95 & -1.61 & Unit root \\
\hline exchange rate & constant & & 1 & -0.86 & -2.66 & -1.95 & -1.61 & Unit root \\
\hline \multicolumn{9}{|l|}{ In first difference } \\
\hline D(Remittances) & constant & & 0 & -2.74 & -2.66 & -1.95 & -1.61 & Stationary \\
\hline D(Agricultural GI & constant & & 1 & -2.87 & -2.66 & -1.95 & -1.61 & Stationary \\
\hline D(exchange rate) & constant & & 1 & -3.75 & -2.66 & -1.95 & -1.61 & Stationary \\
\hline
\end{tabular}

Source: Author's estimates

1/ The test used is the one proposed by Elliott, Rothenberg, and Stock (1996). The null hypothesis is that the variable has a unit root.

2/ The number of lags is selected using the Akaike information criterion. The maximum number of lags used is 6 .

3/ For the regression equations, the critical values are from MacKinnon (1996).

${ }^{16}$ The data are taken from the World Development Indicators database and cover the period 1975-2002. 
Table A6. Jordan: Cointegration Rank Tests (Trace)

\begin{tabular}{ccccc}
\hline $\begin{array}{c}\text { Hypothesized } \\
\text { No. of } \\
\text { Cointegration } \\
\text { Equations }\end{array}$ & Eigenvalue & Statistic & Critical Value & Prob. \\
& & & & 0.05 \\
\\
None & 0.65 & 36.36 & 25.87 & 0.002 \\
At most 1 & 0.37 & 10.93 & 12.52 & 0.091 \\
\hline
\end{tabular}

Source: Author's estimates

Table A7. Jordan: Cointegration Rank Tests (Eigenvalue)

\begin{tabular}{ccccc}
\hline $\begin{array}{c}\text { Hypothesized } \\
\text { No. of } \\
\text { Cointegration } \\
\text { Equations }\end{array}$ & Eigenvalue & Statistic & Critical Value & Prob. \\
& & & & \\
\hline & 0.65 & 25.43 & 19.39 & 0.006 \\
None & 0.37 & 10.93 & 12.52 & 0.091 \\
At most 1 & & & & \\
\hline
\end{tabular}

Source: Author's estimates 
Table A8. Jordan: Statistical Properties of the Vector Error Correction Model 1/

\begin{tabular}{|c|c|c|c|c|c|c|}
\hline \multicolumn{7}{|c|}{ Multivariate tests } \\
\hline & 1 & 2 & 3 & 4 & 5 & 6 \\
\hline LM test & $\begin{array}{r}4.31 \\
{[0.37]}\end{array}$ & $\begin{array}{r}4.80 \\
{[0.31]}\end{array}$ & $\begin{array}{r}3.86 \\
{[0.42]}\end{array}$ & $\begin{array}{r}1.43 \\
{[0.84]}\end{array}$ & $\begin{array}{c}1.51 \\
{[0.82]}\end{array}$ & $\begin{array}{r}1.43 \\
{[0.84]}\end{array}$ \\
\hline Normality JB & & & $\begin{array}{c}5.35 \\
{[0.25]}\end{array}$ & & & \\
\hline Skewness & & & $\begin{array}{c}0.56 \\
{[0.76]}\end{array}$ & & & \\
\hline Excess kurtosis & & & $\begin{array}{c}4.79 \\
{[0.09]}\end{array}$ & & & \\
\hline
\end{tabular}

\begin{tabular}{lrr}
\hline & Univariate tests \\
\hline & Remittances & \multicolumn{2}{c}{ Agricultural } \\
\hline Weak exogeneity & 8.54 & 9.64 \\
& {$[0.00]$} & {$[0.00]$} \\
Exclusion test & 9.80 & 6.8 \\
& {$[0.00]$} & {$[0.01]$} \\
Normality JB & & \\
& 1.74 & 3.61 \\
& {$[0.42]$} & {$[0.16]$}
\end{tabular}

Source: Author's estimates

1/ Numbers in brackets are p-values

\section{Morocco}

We started the econometric analysis of remittances to Morocco by first testing the order of integration of the variables used (Table A9). ${ }^{17}$ All the variables are integrated of order one. After a series of tests, we first estimated a VECM including 3 lags. Both the Johansen and Trace tests suggested the existence of a long-run relation as presented in equation ( 1 ) at 5 percent level of significance (Tables A10, and A11). However, in this VECM, only the first and the third lags turned out to be significant. So we estimated another VECM including only the first and the third lag. The estimated cointegration relation is presented in Table 2 . The statistical properties of the model are described in Table A12. The multivariate LM statistics show that the residuals are not autocorrelated. The multivariate JB test does not reject the

\footnotetext{
${ }^{17}$ The data are taken from the World Development Indicators database and cover the period 1975-2002.
} 
hypothesis of normality of residuals. Exclusion tests suggest that all variables included in the cointegration relation are significant at 5 percent level of significance. Therefore, the model presented in equation ( 1 ) could explain the flow of remittances to Morocco.

Table A9. Morocco: Stationarity Test (Elliott-Rothenberg-Stock DF-GLS test) 1/

\begin{tabular}{|c|c|c|c|c|c|c|c|c|}
\hline Variables & $\begin{array}{l}\text { Included in } \\
\text { regression }\end{array}$ & Lag & $2 /$ & Test statistic & $\begin{array}{c}1 \text { percent critical } \\
\text { value } 3 /\end{array}$ & $\begin{array}{c}5 \text { percent critical } \\
\text { value } 3 /\end{array}$ & $\begin{array}{c}10 \text { percent } \\
\text { critical value } 3 /\end{array}$ & Conclusion \\
\hline \multicolumn{9}{|l|}{ In levels } \\
\hline Remittances & constant & & 0 & -0.45 & -2.65 & -1.95 & -1.61 & Unit root \\
\hline Agricultural GDP & constant & & 1 & -1.16 & -2.66 & -1.95 & -1.61 & Unit root \\
\hline exchange rate & constant & & 1 & -0.96 & -2.66 & -1.95 & -1.61 & Unit root \\
\hline \multicolumn{9}{|l|}{ In first difference } \\
\hline D(Remittances) & constant & & 1 & -4.66 & -2.66 & -1.95 & -1.61 & Stationary \\
\hline D(Agricultural GI & constant & & 0 & -10.58 & -2.66 & -1.95 & -1.61 & Stationary \\
\hline D(exchange rate) & constant & & 4 & -3.20 & -2.67 & -1.95 & -1.61 & Stationary \\
\hline
\end{tabular}

Source: Author's estimates

1/ The test used is the one proposed by Elliott, Rothenberg, and Stock (1996). The null hypothesis is that the variable has a unit root.

2/ The number of lags is selected using the Akaike information criterion. The maximum number of lags used is 6

3/ The critical values are from MacKinnon (1996).

Table A10. Morocco: Cointegration Rank Tests (Trace)

\begin{tabular}{ccccc}
\hline $\begin{array}{c}\text { Hypothesized } \\
\text { No. of } \\
\text { Cointegration } \\
\text { Equations }\end{array}$ & Eigenvalue & Statistic & Critical Value & Prob. \\
& & & & 0.05 \\
\hline None & 0.67 & 50.16 & 42.92 & 0.008 \\
At most 1 & 0.47 & 23.62 & 25.87 & 0.093 \\
At most 2 & 0.30 & 8.44 & 12.52 & 0.218 \\
\hline
\end{tabular}

Source: Author's estimates 
Table A11. Morocco: Cointegration Rank Tests (Maximum Eigenvalue)

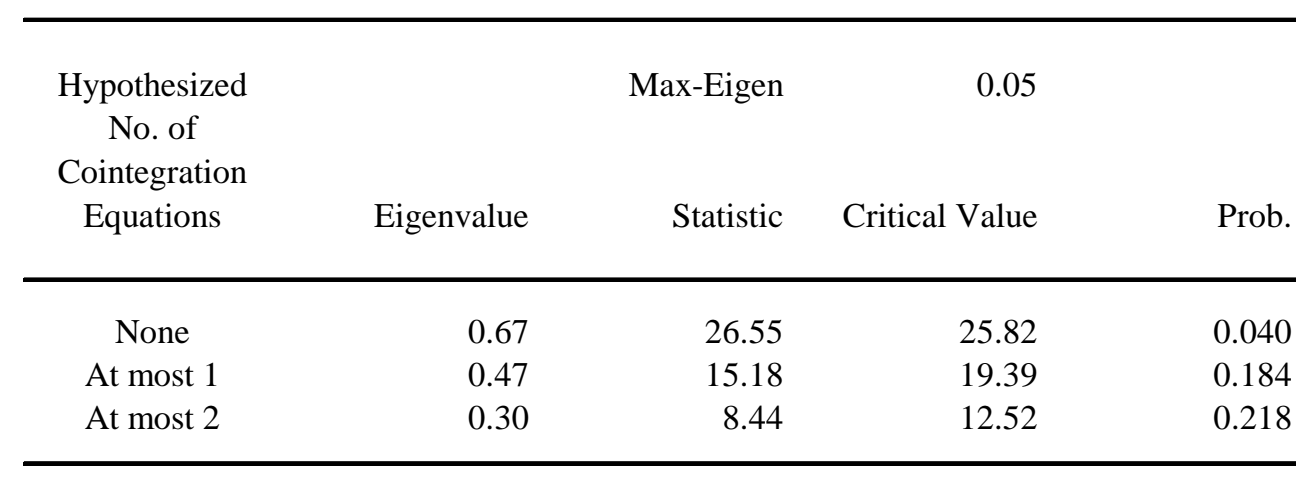

Source: Author's estimates

Table A12. Morocco: Statistical Properties of the Vector Error Correction Model 1/

\begin{tabular}{|c|c|c|c|c|c|c|}
\hline \multicolumn{7}{|c|}{ Multivariate tests } \\
\hline & 1 & 2 & 3 & 4 & 5 & 6 \\
\hline LM test & $\begin{array}{c}13.62 \\
{[0.14]}\end{array}$ & $\begin{array}{c}10.77 \\
{[0.29]}\end{array}$ & $\begin{array}{r}7.50 \\
{[0.58]}\end{array}$ & $\begin{array}{c}10.69 \\
{[0.30]}\end{array}$ & $\begin{array}{r}9.01 \\
{[0.44]}\end{array}$ & $\begin{array}{r}1.02 \\
{[0.999]}\end{array}$ \\
\hline Normality JB & & & $\begin{array}{c}9.19 \\
{[0.16]}\end{array}$ & & & \\
\hline Skewness & & & $\begin{array}{c}2.68 \\
{[0.44]}\end{array}$ & & & \\
\hline Excess kurtosis & & & $\begin{array}{c}6.52 \\
{[0.09]}\end{array}$ & & & \\
\hline
\end{tabular}

Univariate tests

\begin{tabular}{|c|c|c|c|}
\hline \multicolumn{4}{|c|}{ Univariate tests } \\
\hline & Remittances & $\begin{array}{l}\text { Agricultural } \\
\text { GDP } \\
\end{array}$ & Exchange rate \\
\hline \multirow[t]{2}{*}{ Weak exogeneity } & 4.81 & 6.44 & 1.31 \\
\hline & {$[0.03]$} & {$[0.01]$} & {$[0.25]$} \\
\hline \multirow[t]{2}{*}{ Exclusion test } & 3.96 & 4.21 & 7.27 \\
\hline & {$[0.05]$} & {$[0.04]$} & {$[0.01]$} \\
\hline \multirow[t]{2}{*}{ Normality JB } & 3.32 & 2.56 & 3.32 \\
\hline & {$[0.19]$} & {$[0.28]$} & [ 0.19] \\
\hline
\end{tabular}

Source: Author's estimates

1/ Numbers in brackets are p-values 


\section{Pakistan}

We started the econometric analysis by first testing the order of integration of the variables used (Table A13). ${ }^{18}$ All the variables are integrated of order one. After a series of tests, the VECM we estimated included one lag. The Johansen Trace test did not suggest the existence of a cointegration equation at 10 percent level of significance (Table A14). However, the Johansen Eigenvalue test suggested the existence of a long-run relation as presented in equation ( 1 ) at 5 percent level of significance (Table A15). This estimated long-run relation is presented in Table 2. The statistical properties of the VECM are described in Table A16. The multivariate LM statistics shows that the residuals are not autocorrelated. The multivariate JB test does not reject the hypothesis of normality of residuals. Exclusion tests suggest that all variables included in the cointegration relation, with the exception of the exchange rate, are significant at 1 percent level of significance. ${ }^{19}$ Therefore, the model presented in equation ( 1 ) could explain the flow of remittances to Pakistan.

Table A13. Pakistan: Stationarity Test (Elliott-Rothenberg-Stock DF-GLS test) 1/

\begin{tabular}{|c|c|c|c|c|c|c|c|c|}
\hline Variables & $\begin{array}{l}\text { Included in } \\
\text { regression }\end{array}$ & Lag & $2 /$ & Test statistic & $\begin{array}{c}1 \text { percent critical } \\
\text { value } 3 /\end{array}$ & $\begin{array}{c}5 \text { percent critical } \\
\text { value } 3 /\end{array}$ & $\begin{array}{c}10 \text { percent } \\
\text { critical value } 3 /\end{array}$ & Conclusion \\
\hline \multicolumn{9}{|l|}{ In levels } \\
\hline Remittances & constant & & 0 & -1.52 & -2.66 & -1.95 & 1.61 & Unit root \\
\hline Agricultural GDP & constant & & 4 & -0.73 & -2.67 & -1.95 & 1.61 & Unit root \\
\hline exchange rate & constant & & 3 & -1.06 & -2.67 & -1.95 & 1.61 & Unit root \\
\hline \multicolumn{9}{|l|}{ In first difference } \\
\hline D(Remittances) & constant & & 0 & -2.02 & -2.66 & -1.95 & -1.61 & Stationary \\
\hline D(Agricultural GI & constant & & 0 & -6.27 & -2.66 & -1.95 & -1.61 & Stationary \\
\hline D(exchange rate) & constant & & 6 & -2.88 & -2.69 & -1.96 & -1.61 & Stationary \\
\hline
\end{tabular}

Source: Author's estimates

1/ The test used is the one proposed by Elliott, Rothenberg, and Stock (1996). The null hypothesis is that the variable has a unit root.

2 / The number of lags is selected using the Akaike information criterion. The maximum number of lags used is 6

3/ For the regression equations, the critical values are from MacKinnon (1996).

\footnotetext{
${ }^{18}$ The data are taken from the World Development Indicators database and cover the period 1976-2002.

${ }^{19}$ We also estimated another VECM without the exchange rate. Even though the Johansen tests suggested that there was cointegration, the exogeneity tests suggested that the variable "Remittances" was weakly exogenous $\left(\chi^{2}(1)=0.15\right.$, prob $\left.=0.70\right)$. Therefore, such a model could not be considered as providing a potential explanation for the flow of remittances to Pakistan.
} 
Table A14. Pakistan: Cointegration Rank Tests (Trace)

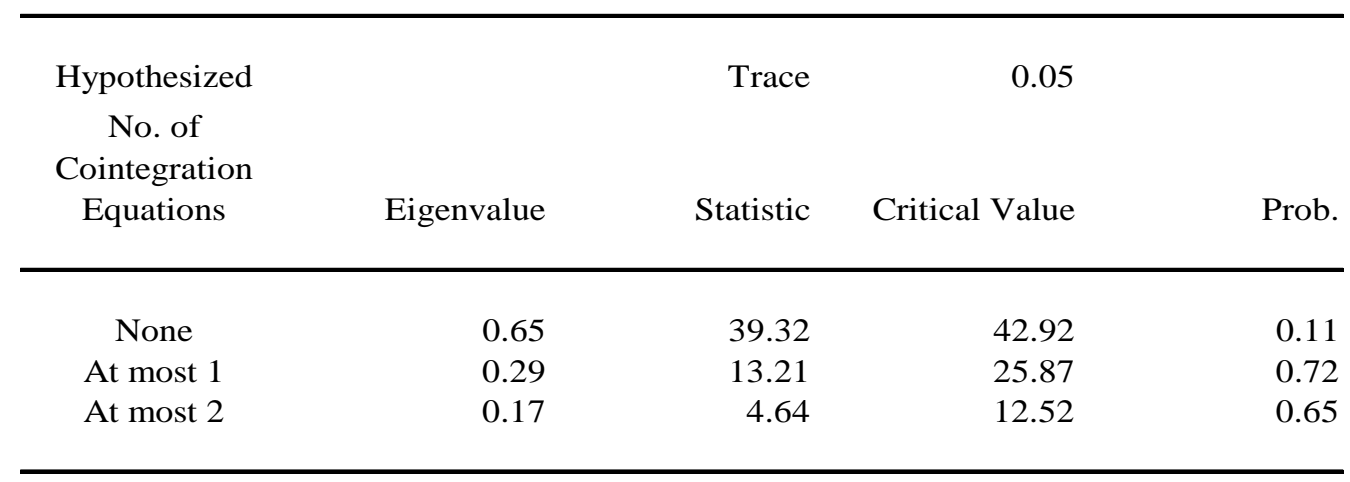

Source: Author's estimates

Table A15. Pakistan: Cointegration Rank Tests (Maximum Eigenvalue)

\begin{tabular}{|c|c|c|c|c|}
\hline Hypothesized & & Max-Eigen & 0.05 & \\
\hline Equations & Eigenvalue & Statistic & Critical Value & Prob. \\
\hline None & 0.65 & 26.11 & 25.82 & 0.046 \\
\hline At most 1 & 0.29 & 8.57 & 19.39 & 0.77 \\
\hline At most 2 & 0.17 & 4.64 & 12.52 & 0.64 \\
\hline
\end{tabular}

Source: Author's estimates 
Table A16. Pakistan: Statistical Properties of the Vector Error Correction Model 1/

\begin{tabular}{|c|c|c|c|c|c|c|}
\hline \multicolumn{7}{|c|}{ Multivariate tests } \\
\hline & 1 & 2 & 3 & 4 & 5 & 6 \\
\hline LM test & 3.15 & 6.30 & 11.24 & 5.43 & 10.61 & 10.88 \\
\hline & 0.96 & 0.71 & 0.26 & 0.80 & 0.30 & 0.28 \\
\hline Normality JB & & & $\begin{array}{c}7.23 \\
{[0.30]}\end{array}$ & & & \\
\hline Skewness & & & $\begin{array}{c}1.57 \\
{[0.67]}\end{array}$ & & & \\
\hline Excess kurtosis & & & $\begin{array}{c}5.66 \\
{[0.13]}\end{array}$ & & & \\
\hline
\end{tabular}

\begin{tabular}{lrrr}
\hline \multicolumn{4}{c}{ Univariate tests } \\
\hline & \multicolumn{3}{c}{ Agricultural } \\
& Gemittances & GDP & Exchange rates \\
\hline \multirow{3}{*}{ Weak exogeneity } & 4.02 & 8.02 & 1.51 \\
& {$[0.04]$} & {$[0.00]$} & {$[0.22]$} \\
Exclusion test & 10.16 & 17.44 & 1.20 \\
& {$[0.00]$} & {$[0.00]$} & {$[0.27]$} \\
Normality JB & & & \\
& 1.83 & 2.83 & 2.57 \\
& {$[0.40]$} & {$[0.24]$} & {$[0.28]$} \\
\hline
\end{tabular}

Source: Author's estimates

$1 /$ Numbers in brackets are p-values

\section{E. Tunisia}

We conducted a first analysis of remittances to Tunisia using the dollar value of remittances, agricultural GDP in local currency, the exchange rate and a trend as described in equation ( 1 ). Even though Johansen tests suggested that there was a cointegration relation among these variables, the weak exogeneity tests indicated that remittances were weakly exogenous in this model $(\chi 2(1)=0.25$, prob=0.62). As far as the model without the exchange rate is concerned, Johansen tests also suggested that there was cointegration among the variables. However, exclusion tests suggested that agricultural GDP may not enter the long-run relation in a significant way, thus leaving remittances being explained only by a trend. To overcome this model uncertainty, we conducted another analysis using only the values of the variables in local currency. 
We first tested the order of integration of the variables (in local currency) that we used (Table A17). ${ }^{20}$ All the variables are integrated of order one. After a series of tests, we included fours lags in the VECM we estimate. Results from the Johansen eigenvalue cointegration test did not seem conclusive (Table A19). However, the Johansen trace test suggested the existence of a long-run relation as presented in equation ( 1 ) at 5 percent level of significance (Table A18). The estimated long-run relation is presented in Table 2. The statistical properties of the VECM are described in Table A20. The multivariate LM statistics shows that the residuals are not autocorrelated. The multivariate JB test does not reject the hypothesis of normality of residuals. Exclusion tests suggest that all variables included in the cointegration relation are significant. Therefore, the model presented in equation ( 1 ) could explain the flow of remittances to Tunisia.

Table A17. Tunisia: Stationarity Test (Elliott-Rothenberg-Stock DF-GLS test) 1/

\begin{tabular}{|c|c|c|c|c|c|c|c|c|}
\hline Variables & $\begin{array}{l}\text { Included in } \\
\text { regression }\end{array}$ & Lag $2 /$ & & Test statistic & $\begin{array}{c}1 \text { percent critical } \\
\text { value } 3 /\end{array}$ & $\begin{array}{c}5 \text { percent critical } \\
\text { value } 3 /\end{array}$ & $\begin{array}{c}10 \text { percent } \\
\text { critical value } 3 /\end{array}$ & Conclusion \\
\hline \multicolumn{9}{|l|}{ In levels } \\
\hline Remittances & constant & & 0 & 0.40 & -2.66 & -1.95 & -1.61 & Unit root \\
\hline Agricultural GDP & constant & & 0 & -1.07 & -2.66 & -1.95 & -1.61 & Unit root \\
\hline \multicolumn{9}{|l|}{ In first difference } \\
\hline D(Remittances) & constant & & 0 & -4.21 & -2.66 & -1.95 & -1.61 & Stationary \\
\hline D(Agricultural GDP ) & constant & & 0 & -5.14 & -2.66 & -1.95 & -1.61 & Stationary \\
\hline \multicolumn{9}{|c|}{ Source: Author's estimates } \\
\hline
\end{tabular}

Table A18. Tunisia: Cointegration Rank Tests (Trace)

\begin{tabular}{|c|c|c|c|c|}
\hline Hypothesized & & Trace & 0.05 & \\
\hline $\begin{array}{c}\text { No. of Cointegration } \\
\text { Equations }\end{array}$ & Eigenvalue & Statistic & Critical Value & Prob. \\
\hline None & 0.53 & 27.81 & 25.87 & 0.028 \\
\hline At most 1 & 0.40 & 11.31 & 12.52 & 0.079 \\
\hline
\end{tabular}

Source: Author's estimates

${ }^{20}$ The data are taken from the World Development Indicators database and cover the period 1976-2002. 
Table A19. Tunisia: Cointegration Rank Tests (Maximum Eigenvalue)

\begin{tabular}{ccccr}
\hline $\begin{array}{c}\text { Hypothesized } \\
\begin{array}{c}\text { No. of Cointegration } \\
\text { Equations }\end{array}\end{array}$ & Eigenvalue & Statistic & Critical Value & Prob. \\
& & & & \\
\hline None & 0.53 & 16.50 & 19.39 & 0.125 \\
At most 1 & 0.40 & 11.31 & 12.52 & 0.079 \\
& & & & \\
\hline
\end{tabular}

Source: Author's estimates

Table A20. Tunisia: Statistical Properties of the Vector Error Correction Model 1/

\begin{tabular}{|c|c|c|c|c|c|c|}
\hline \multicolumn{7}{|c|}{ Multivariate tests } \\
\hline & 1 & 2 & 3 & 4 & 5 & 6 \\
\hline LM test & 2.97 & 2.73 & 1.70 & 0.38 & 0.92 & 2.75 \\
\hline & {$[0.56]$} & {$[0.60]$} & {$[0.79]$} & [ 0.98] & {$[0.92]$} & [ 0.60] \\
\hline Normality JB & & & $\begin{array}{c}8.18 \\
{[0.09]}\end{array}$ & & & \\
\hline Skewness & & & 0.06 & & & \\
\hline Excess curtosis & & & $\begin{array}{c}8.12 \\
{[0.02]}\end{array}$ & & & \\
\hline
\end{tabular}

\begin{tabular}{lrr}
\hline \multicolumn{3}{c}{ Univariate tests } \\
\hline & Remittances & Agricultural \\
\hline & 3.00 & 1.03 \\
Weak exogeneity & {$[0.08]$} & {$[0.31]$} \\
& & \\
Exclusion test & 5.07 & 3.27 \\
& {$[0.02]$} & {$[0.07]$} \\
Normality JB & & \\
& 4.43 & 3.75 \\
& {$[0.11]$} & {$[0.15]$} \\
\hline
\end{tabular}

Source: Author's estimates

1/ Numbers in brackets are p-values 